\title{
Calcific degeneration and late fracture of expanded polytetrafluoroethylene neochords after mitral valve repair
}

\author{
Suvitesh Luthra, FRCS-CTh, Abdelhadi Ismail, IMRCS, and Geoff Tsang, FRCS-CTh, Southampton, \\ United Kingdom
}

\footnotetext{
From the Cardiac Surgery Unit, Division D, University Hospital Southampton NHS Trust, Southampton, United Kingdom.

Disclosures: Authors have nothing to disclose with regard to commercial support.

Received for publication Oct 21, 2019; revisions received Oct 21, 2019; accepted for publication Nov 29, 2019; available ahead of print Feb 12, 2020.

Address for reprints: Suvitesh Luthra, FRCS-CTh, Cardiac Surgery Unit, Division D, University Hospital Southampton NHS Trust, Southampton General Hospital, North Wing Mail Point, Southampton SO16 6YD, United Kingdom (E-mail: hadi.ismail@doctors.org.uk).

JTCVS Techniques 2020;1:34-6

2666-2507

Copyright $(2020$ The Author(s). Published by Elsevier Inc. on behalf of The American Association for Thoracic Surgery. This is an open access article under the CC BY-NC-ND license (http://creativecommons.org/licenses/bync-nd/4.0/).

https://doi.org/10.1016/j.xjtc.2019.11.012
}

\section{CASE REPORT}

An 84-year-old woman represented with increasing shortness of breath and a new pan systolic murmur at the apex 12 years following a mitral valve repair (for severe mitral regurgitation due to $\mathrm{P} 2$ prolapse), tricuspid valve repair, and ablation of atrial fibrillation. At the initial operation, the flail posterior leaflet was supported with two CV 4 polytetrafluoroethylene (ePTFE) neochords (Gore-Tex; W. L. Gore \& Associates Inc, Flagstaff, Ariz) and a 32-mm ring annuloplasty. The previous intraoperative, predischarge and follow-up echocardiograms confirmed no residual prolapsed/billowing or mitral regurgitation. Echocardiogram now confirmed severe mitral regurgitation from a flail P2 and dense echogenicity of chords (Figure 1). History and blood results did not show renal impairment or abnormality of calcium metabolism. Intraoperatively, the neochords were found to be stiff and calcified (Figure 2). One of the neochords was fractured and the other had signs of stiffening, calcific degeneration, and imminent fracture. The subchordal apparatus was thickened and restrictive hence the valve was deemed unrepairable. The pattern of calcification seen in the neochords was not replicated in the remaining subchordal apparatus and surrounding tissues. The annuloplasty ring was explanted and a 31-mm bioprosthesis was implanted with preservation of the posterior chordal apparatus.

Postoperative recovery was uneventful with satisfactory postoperative echocardiograms. Unfortunately, histopathology or electron microscopy was not obtained.

\section{DISCUSSION}

ePTFE neochords are widely used in mitral valve repair due to its strength, inertness, hydrophobic properties and degeneration.

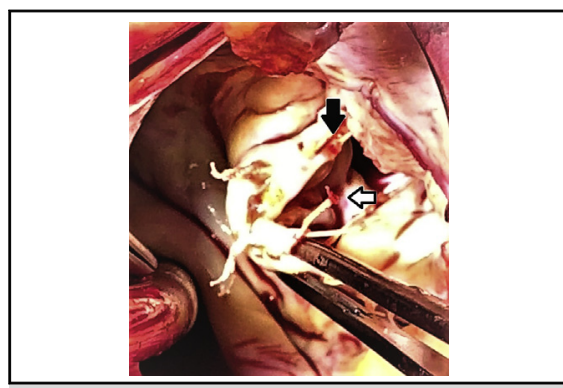

Calcified ruptured expanded polytetrafluoroethylene neochord (white arrow) and strained neochord with imminent rupture (black arrow).

\section{CENTRAL MESSAGE}

EPTFE neochords can rarely undergo calcific degeneration and fracture causing a late failure of mitral valve repair.

See Commentaries on pages 37 and 39.

nonimmunogenicity. The structure of ePTFE is made of highly microporous sheets of ePTFE that allow water vapor to pass through but retain hydrophobic properties due to the strong electronegativity of fluorine atoms. ePTFE is chemically inert. Unlike the biological substitutes with phospholipid cell membranes that undergo amorphous dystrophic calcification and degeneration over time, ePTFE is not known to imbibe calcium or undergo calcific

ePTFE patches have been used extensively in congenital cardiac surgery for ventricular and atrial septal defect closure and right ventricular outflow and pulmonary valve reconstructions. Kumar and colleagues ${ }^{1}$ reported excellent results with right ventricular outflow tract reconstruction with a PTFE monocusp valve over a 20 -year period. The sheer and compressive stresses on patches in these reconstructions differ from the tensile and frictional stresses experienced by neochords in mitral valve repairs. Excellent long-term results with ePTFE neochords in mitral valve repair have been reported. ${ }^{2,3}$ There have been, however, isolated reports of early and late failures. ${ }^{4,5}$ 


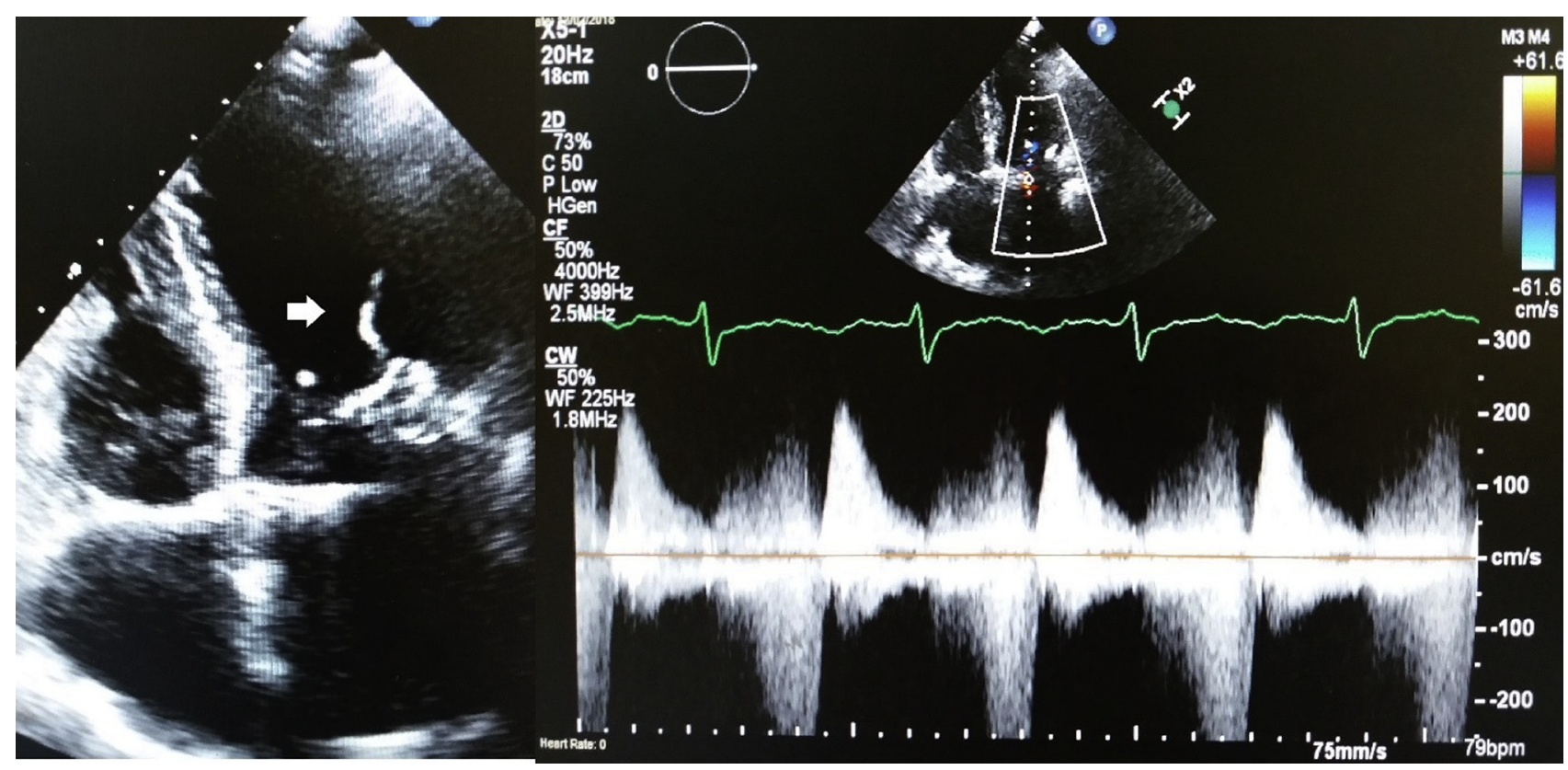

FIGURE 1. Calcified, ruptured expanded polytetrafluoroethylene neochord (white arrow) in the setting of severe mitral regurgitation.

ePTFE carries an electrostatic negative charge on the surface and initially repels blood elements and bacteria. The microporous structure is gradually filled in by platelets and clots that organize to form a dense fibrous tissue ingrowth covered later by endothelial cells. Structural analysis up to a decade later shows that neochords remain

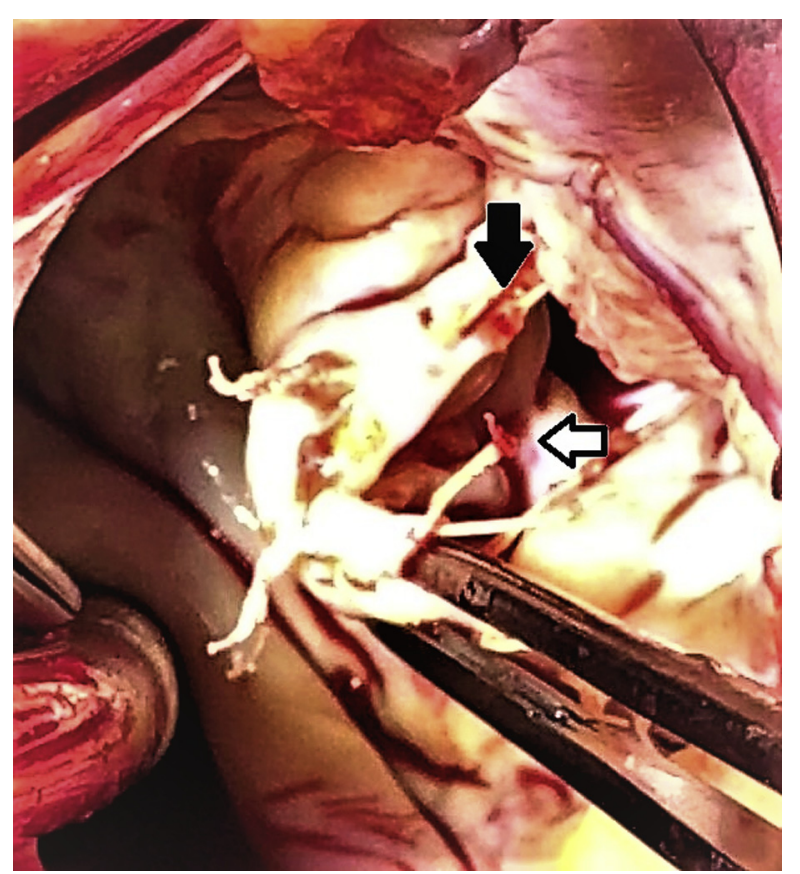

FIGURE 2. Calcified ruptured expanded polytetrafluoroethylene neochord (white arrow) and strained neochord with imminent rupture (black arrow). supple and retain their flexibility and strength after this process completes. ${ }^{6}$ ePTFE repels bacteria due to its surface electronegativity. However, due to its highly porous microstructure, it is extremely difficult to eradicate infection once it sets in. It is extremely resistant to chemicals and does not lyse or degrade on exposure to microbiological enzymes that normally destroy the surrounding biological tissues leading to loosening and extrusion of implants. Dystrophic calcification of infection-related fibrin deposits can potentially weaken the structure. There was no evidence of infection in this case.

The extensive calcific degeneration as a mechanism of rupture has been rarely reported. ${ }^{7}$ It is possible that fibrosis in the interstices of the microporous structure attracts calcium from blood despite the endothelial cover. The CV 4 ePTFE neochords can withstand $1000 \mathrm{~g}$ tensile load. ${ }^{8,9}$ Even after being crushed by forceps, this strength is at least 500 g. ${ }^{8,9}$ The typical tensile strain on the chords in mitral valve repairs at the site of primary chordal attachment in the P2 segment is 50 g. ${ }^{8,9}$ Slow calcification of the interstitial fibrosa in the neochord can potentially cause stiffening and loss of tensile strength in the weakened microstructure. These calcified neochords possibly can fracture under even normal tensile loads as seen in our case. This is distinctly different from early fracture related to ePTFE injury by forceps or mechanical stress induced by chordal length.

Concerns have been raised regarfing neochord damage by energy transfer during atrial fibrillation ablation. ePTFE is electrically inert and thermally stable. Ablation is performed before placement of neochords and is unlikely to cause damage. 
The cause of this rare calcification in our case is unclear and nonetheless calls for yearly echocardiographic follow-up.

\section{References}

1. Kumar M, Turrentine MW, Rodefeld MD, Bell T, Brown JW. Right ventricular outflow tract reconstruction with a polytetrafluoroethylene monocusp valve: a 20-year experience. Semin Thorac Cardiovasc Surg. 2016;28:463-70.

2. David TE, Armstrong S, Ivanov J. Chordal replacement with polytetrafluoroethylene sutures for mitral valve repair: a 25-year experience. J Thorac Cardiovasc Surg. 2013;145:1563-9.

3. Salvador L, Mirone S, Bianchini R, Regesta T, Patelli F, Minniti G, et al. A 20-year experience with mitral valve repair with artificial chordae in 608 patients. Thorac Cardiovasc Surg. 2008;135:1280-7.
4. Yamashita MH, Skarsgard PL. Intermediate and early rupture of expanded polytetrafluorethylene neochordae after mitral valve repair. Ann Thorac Surg. 2011; 92:341-3.

5. Castillo JG, Anyanwu AC, El-Eshmawi A, Gordon RE, Adams DH. Early rupture of an expanded polytetrafluoroethylene neochord after complex mitral valve repair: an electron microscopic analysis. J Thorac Cardiovasc Surg. 2013;145: e29-31.

6. Minatoya K, Kobayashi J, Sesako Y, Ishibashi-Ueda H, Yutani C, Kitamura S. Long-term pathological changes of expanded polytetrafluorethylene suture in the human heart. J Heart Valve Dis. 2001;10:139-42.

7. Farivar RS, Shernan SK, Cohn LH. Late rupture of polytetrafluoroethylene neochordae after mitral valve repair. J Thorac Cardiovasc Surg. 2009;137:504-6.

8. Hertwick SP, von Fraunhofer JA, Materson BJ. Tensile characteristics of PTFE sutures. Biomaterials. 1986;9:457-9.

9. Salisbury PF, Cross CE, Reuben PA. Chorda tendinea tension. Am J Physiol. 1965; 206:385-92. 